\title{
Semblanza de Pérez Petit
}

HEmos venido a celebrar, al término de una trayectoria heroica de cincuenta años, la conquista de una gran esperanza.

Espero, dijo a la duda omnipresente y a la saña emboscada del tiempo y de los hombres. Espero, dijo al dolor, mientras transcurrían los días y las décadas de su vasto y magno esfuerzo, este Víctor Pérez Petit.

El mismo nos refiere, en una confesión desnuda de solemnidad y de retórica, de qué modo brotó del hondón de su alma esa palabra, Espero, mientras ordenaba el material de sus Obras completas, caudal de amor y de fe, en tanto que retoñaba, en "una alegría de esmeralda", la savia de su espíritu.

Con la fe y la pasión de su arte, de su trabajo y de su conducta, este obrero esperó. Su caso personal y su vida estoica reeditan el drama del escritor iberoamericano, frente a la incomprensión y a la injusticia.

Desde esta eminencia de su consagración y de su triunfo, nos es dado abarcar las limpias perspectivas de su pensamiento y de su obra. Nos es dado divisar, desde luego, el campo abrupto de la brega inicial: escollos y reductos de la reacción, que no quiere pasar; vórtices de la inercia y del misoneísmo, que se disfraza de indiferencia, de vacío y de silencio.

Esperaba entonces el joven cruzado, a pesar de la diatriba, la persecución y la venganza, cuando el ambiente - tal como él lo describe- planteaba la ecuación de la vida en los términos cerrados del esfuerzo mínimo y del exclusivo provecho propio.

Honramos ahora en Pérez Petit al ilustre polígrafo uruguayo, a aquel núcleo juvenil que levantó, en el plácido horizonte de la aldea, el pórtico de una nueva cultura. 
Fué preciso poner al servicio de tamaña empresa, junto al pensamiento y a la sensibilidad, una renovada estructura moral. Oigámosle: "La verdad fué el norte de nuestras actividades; un libro era nuestra fortuna ; un sueño, nuestra finalidad ; la mayor gloria, el aplauso de un maestro para las elucubraciones de nuestro ingenio."

Era la época de la Revista de Literatura y Ciencias Sociales, uno de los más representativos exponentes de la intelectualidad de nuestro páís y de América, por su difusión y por su enjundia, de las nuevas normas literarias y filosóficas. Fué crisol de ideas, de orientaciones y doctrinas.

Traspuesta, con la generación del Ateneo, la etapa del romanticismo militante, de allí partió la osada anunciación, y acentuóse todavía más cuando se pretendió articular una pauta propia en moral y en estética. De esta generación y de ese núcleo nos viene el alto ensayista y el crítico que hoy, transcurrida la media centuria, formula en el umbral de su magna obra un Decálogo espiritual y lo dicta para los nuevos, con la autoridad de su experiencia y la dignidad de su ejemplo. Testamento que entraña la clara enunciación de las más altas normas para la acción mental, frente a la responsabilidad del escritor y el artista; hombre de ciencia o de derecho; historiador o filósófo. Madurado a la sombra del árbol del conocimiento, cuyas ramas se expanden en todas las direcciones de la cultura, la tierra y la savia de las humanidades, ese Testamento espiritual nos advierte cómo los pueblos contemporáneos que se apartan de ellas, se inhiben de formar las élites indispensables a la vida nacional.

Hemos procurado captar, a todo lo largo y lo profundo de ese esfuerzo de cincuenta años, las dimensiones de una obra - densos volúmenes de las más diversas disciplinas del pensamiento, toda su sangre y toda su luz-, y se dibujan en el espacio atónito de nuestro espíritu, unas veces por sus remotos resplandores, y otras a impulso de una viva, imperiosa y actual iluminación. Hemos procurado seguirlo en su vibrante itinerario y acompañarlo a través de todos los accidentes del rudo peregrinaje de su corazón, situándose ante su visión retrospectiva, sus recónditas infinitudes, hasta llegar al punto de arribo espiritual del hombre contemporáneo.

Acaso ha de interesar, sobre todo, a este caballero de la inteligencia, como el más alto relieve del homenaje, la descripción de ese intento y su angustiada inquietud. "Quiero cansarme de todo, menos de comprender": tal ha sido su lema. Y con el dinamismo ya sereno, 
ya impetuoso, de su mente y de su voluntad, trabaja que te trabaja, quiso comprenderlo todo. De él podríamos decir lo que de Lucrecio dijo Virgilio: "Felix que potiut rerum cognescere causas": "Feliz aquel a quien le es dado conocer la razón de las cosas."

Veamos cómo despunta su acción de iniciado frente al sedentarismo provinciano de la época y a la muralla de piedra de sus preconceptos. Comienza, entonces, a sentirse el arresto sistemático y a menudo certero de quien fué en nuestro medio - por la agudeza de sus disciplinas, y por el aporte creciente de sus métodos, su información y el dominio oceánico de los temas- nuestro primer humanista integral.

Spéctacle magnifique -aunque discrepemos con algunas de las directivas de su pensamiento-- el de Víctor Pérez Petit, renovador de hombres y de ideas, que se inicia en aquella época "múltiple y contradictoria", como la describe Alberto Zum Felde en su ensayo fundamental, y así en el plano de la literatura tanto como en el de la filosofía. Es cuando to presenta el autor de Proceso intelectual del Uruguay, quien recibió más tarde de sus manos el cetro de la alta crítica, descubriendo las nuevas figuras originales y los pensamientos revolucionarios de la hora, pero sin descuidar el ser otero espiritual indolatino: de ámbito ecuménico, pero sobre los estratos de nuestra propia alma. Mantuvo su actitud meditativa frente al ritmo sincopado de los neófitos; se salvó del desconsuelo romántico, lo mismo que de la dispersión y el torbellino subsiguientes, y nunca perdió la serenidad ni su equilibrio.

Epoca aquella, múltiple y contradictoria en verdad, ¿pero acaso lo fué más que ésta que nosotros vivimos, en la que se sitúa la etapa culminante de su labor magistral? Y han transcurrido, mientras tanto, los cincuenta años de su brega y el afán de su espíritu... Y continúa la inquietud zozobrante atenaceando a los que se resisten a ser prófugos de su propia alma.

Proclama el maestro su idealismo primigenio, a pesar de Taine, de Spencer y de otros adustos pontífices de su generación, hoy cuando rigen el mecanismo, el determinismo de raza y la poderosa técnica industrial puestos al servicio de la matanza y al oro del in-. perialismo o a una demagogia capaz de uncir el rebaño de los hombres al yugo de los falsos apóstoles.

La misma interrogante nos asedia, en toda su trágica ansiedad, mientras desfilan los diversos panoramas, a partir de aquel kaleidos- 
copio finisecular. $\mathrm{Y}$ a través de las promesas de la aurora y la indefinición de los crepúsculos; de las escuelas y las capillas estéticas; las doctrinas y las ideologías filosóficas, sociales, económicas; y del fetichismo de las grandes palabras, aguardamos nosotros todavía AL QUE VENDRÁ, como ellos lo aguardaron en su hora. Se renueva el mensaje emocional de Rodó, también venerable de cincuenta años. Nuestro corazón y nuestro pensamiento están todavía llenos de la misma incertidumbre. El fin del siglo, que él consideró como un ocaso tanto en el tiempo como en la historia de las ideas, ¿ continúa en este meridiano de la nueva centuria? ¿O es que ha caído el pensamiento en la noche de la tragedia humana como en un "lecho sombrio"?

Pero en duda y dolor y sacrificio, este amigo de José Enrique Rodó y los integrantes del núcleo anunciador —voces proféticas y esfuerzo creador, latentes durante medio siglo - echaron las bases de un humanismo nuestro y de América. Habíamos conquistado el espacio, pero nos faltaba conquistar el tiempo. Ese humanismo se situó ante el espectáculo de los siglos traspuestos y el fragor de las influencias y de las culturas y de todas las ideas contradictorias. Se buscó armonizarlas como formas diversas de humanidad incompleta, en cuyas diferencias y en cuyas negaciones radican acaso la armonía y la afirmación del mañana. $Y$ no es otro el sentido que tiene la vieja palabra humanitas, al ser rescatada, del diálogo de Cicerón, del polvo y la humedad de mil quinientos años, por los primeros exploradores de la conciencia moderna, desde Petrarca y Lorenzo Valla, hasta Erasmo, Vives y Juan de Valdés.

En duda, en dolor y sacrificio se está amasando ese humanismo, aun frente a la tragedia actual del mundo, y cuando se ha pronunciado de nuevo la palabra Apocalipsis, asimilando sus imágenes a aquellas que adoptó el viejo judaísmo de los mitos de Oriente. Nueva Epopeya en duda, en dolor y en sacrificio... Nos vinculan al humanismo clásico la responsabilidad del drama ideológico y emocional, y el hecho de existir, en esta época de confusionismo y de insensibilidad intelectual, quienes se niegan a participar en la labor de redimir al hombre en este mundo actual donde imperan la esclavitud y la opresión, y quienes se rebelan contra un mundo materialista que no supo, que no quiso aquilatar aquello que está más allá del orden de las cosas. 
Algo efectivo, sin embargo, hemos venido a celebrar ahora: el aporte invalorable de Pérez Petit a nuestra cultura. Y es éste el aspecto cuyo somero comentario se me ha hecho el honor de confiar. Hemos venido a exaltar una vida de transparentes horizontes ofrendada al arte; una obra monumental, toda sinceridad y toda emoción; crónica fidedigna de una alma por él mismo engarzada desde su primera página, en la estrofa pindárica, arrancada al estadio del alma para la alegría fecunda de la razón y de la belleza.

$Y$ si su nombre y su esfuerzo se identifican de tal modo con nuestra cultura, es porque ni él ni los demás combatientes de la misma causa han construído sobre pilares de humo, sino sobre emociones, conducta humana; y cuya trasmisión se opera en el orden horizontal pautas e ideas, "cuya resultante y cuyo criterio de valuación es la del espacio, por comunicación entre los coetáneos, y en el orden vertical del tiempo, por tradición entre las generaciones".

Su obra, que es la historia de su alma, y su ejemplo, que es signo de- un carácter, nos dan por sí solos una definición precisa. Rendimos este homenaje para exaltarla. $Y$ por eso, al terminar, recuerdo otra interpretación de la cultura. Es la que yo prefiero. Pertenece al patriarca de las letras americanas, don Baldomero Sanín Cano, y la formuló en la reunión de Santiago de Chile de Comisiones Nacionales de Cooperación Intelectual, cuyos entrétiens me correspondió el honor. de presidir. La cultura debe adaptarse a los requerimientos de la inteligencia humana; al adaptarla es preciso extraer de la naturaleza misma los elementos de progreso, por los que el hombre, al mejorar su condición, domina las circunstancias y modifica, en su provecho, a la naturaleza. No la constituyen tan sólo los altos pensamientos, las teorías y las conquistas científicas. Es también uno de sus agentes el comercio. Los Argonautas que fueron a buscar el oro, fundaron una civilización. Reclama, además, una base popular extensa. Las naciones incapaces de difundirla, de respetarla y de cultivarla carecen de capacidad ideal y biológica de civilización.

Este que ofrecemos a Víctor Pérez Petit, es un acto de afirmación de la cultura. Ha sabido honrarla, honrándose una vez más, la Junta Nacional de Teatro.

José G. Antuña, Montevideo. 
